\title{
Morphological and Anatomical Variations in Rheophytic Ecotype of Violet, Viola mandshurica var. ikedaeana (Violaceae)
}

\author{
Ryosuke Matsui ${ }^{1}$, Shogo Takei ${ }^{2}$, Kyohei Ohga ${ }^{2}$, Hiroshi Hayakawa ${ }^{1}$, Masataka Yoshida ${ }^{3}$, \\ Jun Yokoyama ${ }^{4}$, Katsura Ito ${ }^{1}$, Ryo Arakawa ${ }^{1}$, Toshiro Masumoto ${ }^{1}$, Tatsuya Fukuda ${ }^{{ }^{*}}$ \\ ${ }^{1}$ Faculty of Agriculture, Kochi University, Kochi, Japan; ${ }^{2}$ Graduate School of Integrated Arts and Sciences, Kochi University, Kochi, \\ Japan; ${ }^{3}$ Graduate school of Science and Engineering, Yamagata University, Yamagata, Japan; ${ }^{4}$ Faculty of Science, Yamagata Uni- \\ versity, Yamagata, Japan. \\ Email: ${ }^{*}$ ffukuda@kochi-u.ac.jp
}

Received February $27^{\text {th }}, 2013$; revised March $29^{\text {th }}, 2013$; accepted April $9^{\text {th }}, 2013$

Copyright (C) 2013 Ryosuke Matsui et al. This is an open access article distributed under the Creative Commons Attribution License, which permits unrestricted use, distribution, and reproduction in any medium, provided the original work is properly cited.

\begin{abstract}
We compared the leaf morphology and anatomy of the putative rheophytic ecotype of Viola mandshurica W. Becker var. ikedaeana (W. Becker ex Taken.) F. Maek. and its closely related variety, V. mandshurica var. mandshurica. We showed that the leaf of the rheophytic ecotype of $V$. mandshurica var. ikedaeana was narrower than that of $V$. mandshurica var. mandshurica. Moreover, the leaf thickness and guard cell size of the rheophytic ecotype of $V$. mandshurica var. ikedaeana were significantly larger than those of $V$. mandshurica var. mandshurica. We further showed that leaves of the rheophytic ecotype of $V$. mandshurica var. ikedaeana contained fewer cells than did those of $V$. mandshurica var. mandshurica. Our results suggest that the narrower leaves of $V$. mandshurica var. ikedaeana are caused by a decrease in the number of cells. A narrower leaf may enable the rheophytic ecotype of $V$. mandshurica var. ikedaeana to resist the strong flow of water that occurs after heavy rainfall, while a thicker leaf may enhance tolerance to desiccation and highintensity light.
\end{abstract}

Keywords: Ecotype; Leaf; Rheophyte; Stenophyllization; Viola mandshurica

\section{Introduction}

Irregular flooding can be an important stress factor for plants that do not inherently possess or are not able to develop traits enabling survival under submerged conditions. Spring and summer floods, which occur after strong rainfall [1], have a particularly strong impact on plant survival [2-4]. Plants that occur in the environment along the river, called rheophytes, are subjected to flash floods as a strong selective pressure. Morphological and anatomical differences in vegetative characters between a rheophyte and its closely related species appear, at least in part, to be correlated with differences in ecological setting [5]. Rheophytic species generally have narrow lanceolate or cuneate leaves [6-8], suggesting that similar adaptive modifications may have occurred independently within various plant families [5]. Some anatomical studies of angiosperm rheophytes have been conducted on

"Corresponding author. the basis of morphological modifications. In the Asteraceae, the narrow leaves of the rheophyte Farfugium japonicum (L. fil.) Kitam. var. luchuense (Masam.) Kitam. were shown to evolve through a decrease in the number of cells across the width of the leaf [9]. Moreover, the variations of leaf-width in the rheophyte Dendranthema yoshinaganthum (Makino ex Kitam.) Kitam. and Aster microcephalus (Miq.) Franch. et Sav. var. ripensis Makino were found to involve the size and number of leaf cells $[10,11]$. In the Campanulaceae, evolution of the rheophytic type of Adenophora triphylla (Thunb.) A.DC. var. japonica (Regel) H. Hara was also shown to involve the size and number of leaf cells [12]. Meanwhile, the rheophytic types of Rhododendron indicum (L.) Sweet f. otakumi T. Yamaz. and R. ripense Makino (Ericaceae) were found to evolve through a decrease in the number of leaf cells $[13,14]$. All of these anatomical studies were conducted on plants in the asterid group, according to angiosperm phylogeny [15-18]. A compre- 
hensive understanding of the general tendency among angiosperms requires investigation of rheophytes belonging to plant groups other than the Asterid Group. In the present study, we focused on members of the Violaceae belonging to the rosid group of core dicotyledons.

Viola mandshurica W.Becker var. ikedaeana (W. Becker ex Taken.) F. Maek. is distributed in mountains on the Japanese mainland (western Honshu, Shikoku, and Kyushu), and also in Korea and Taiwan $[19,20]$. In addition, we newly found the variety on riversides (Figure 1), and it has hastate leaves that are narrower than the triangular- and oblong-lanceolate leaves of its closely related variety, V. mandshurica var. mandshurica. Comparative morphological and anatomical analyses, using the putative rheophytic ecotype of $V$. mandshurica var. ikedaeana, have not previously been conducted, and the leaf modification process of $V$. mandshurica var. ikedaeana (for example, a decrease in cell number and/or size) remains to be elucidated. A widely used indicator for rheophytic leaf size is the leaf index, i.e., the ratio of leaf length to leaf width [21], which has been shown to differ significantly between rheophytes and closely related taxa. In the present study, we investigated the morphological and anatomical differentiation of the putative rheophytic ecotype of $V$. mandshurica var. ikedaeana, by conducting comparative morphological and anatomical analyses between this species and its closely related variety, $V$. mandshurica var. mandshurica.

\section{Materials and Methods}

\subsection{Plant Materials}

All samples of $V$. mandshurica var. mandshurica and the

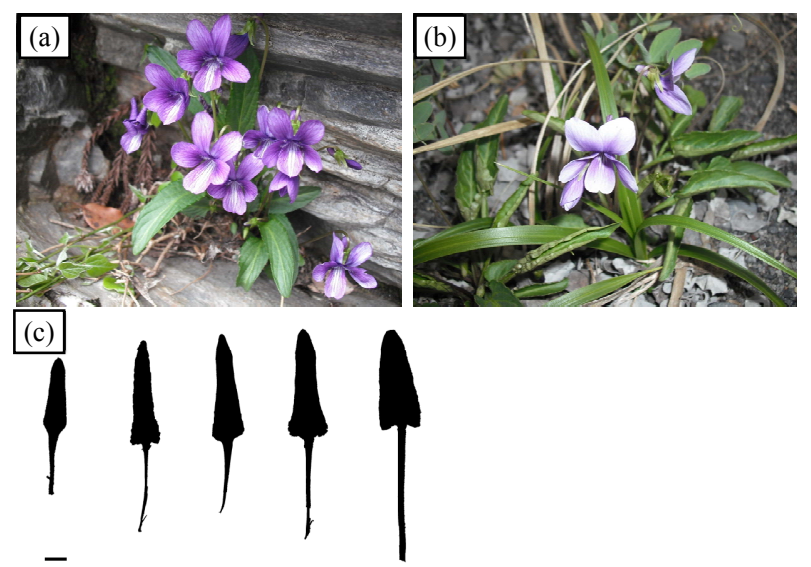

Figure 1. Viola mandshurica varieties. (a) Rheophytic ecotype of V. mandshurica var. ikedaeana; (b) V. mandshurica var. mandshurica; (c) Selected leaf silhouettes of $V$. mandshurica var. ikedaeana showing wide range of leaf shape. Bar $=1 \mathrm{~cm}$. rheophytic ecotype of $V$. mandshurica var. ikedaeana examined in this study were collected from the field. We collected samples from 6 localities (2 localities for $V$. mandshurica var. mandshurica and 4 localities for the rheophytic ecotype of $V$. mandshurica var. ikedaeana). The collection localities are shown in Figure 2 and Table 1. In this study, we collected all individuals of $V$. mandshurica var. ikedaeana ranged from typical morphology of the variety to intermediate morphology with $V$. mandshurica var. mandshurica from riversides to investigate whether the rheophytic ecotype under floods and to evaluate the morphological and anatomical differentiation. We analysed 48 individuals of $V$. mandshurica var. mandshurica (Asakura, 18; Noichi, 30), and a total of 115 individuals of $V$. mandshurica var. ikedaeana, representing 2 populations of the Shimanto (Towa, 25; Nakahira, 30) and Yoshino rivers (Nanato, 30; Oboke, 30).

\subsection{Morphological Analyses}

For morphological analysis, individuals were measured for the following continuous macromorphological leaf variables: 1) length and width of the leaf blade; 2) leaf thickness; and 3) angle of the leaf base. Measurements were made using a digimatic calliper (CD-15CXR; Mitutoyo, Kanagawa, Japan) and a digimatic outside micrometer (MDC-SB; Mitutoyo, Kanagawa, Japan). The leaf size was calculated by using the following formula: (leaf length $\times$ leaf width) $/ 2$. The leaf index was calculated as the ratio of the leaf length to the leaf width, according to [21].

\subsection{Anatomical Analyses}

For anatomical analysis, fully expanded leaves were collected from each individual. To count the number of cells on the blade, the adaxial surface of the leaves was peeled

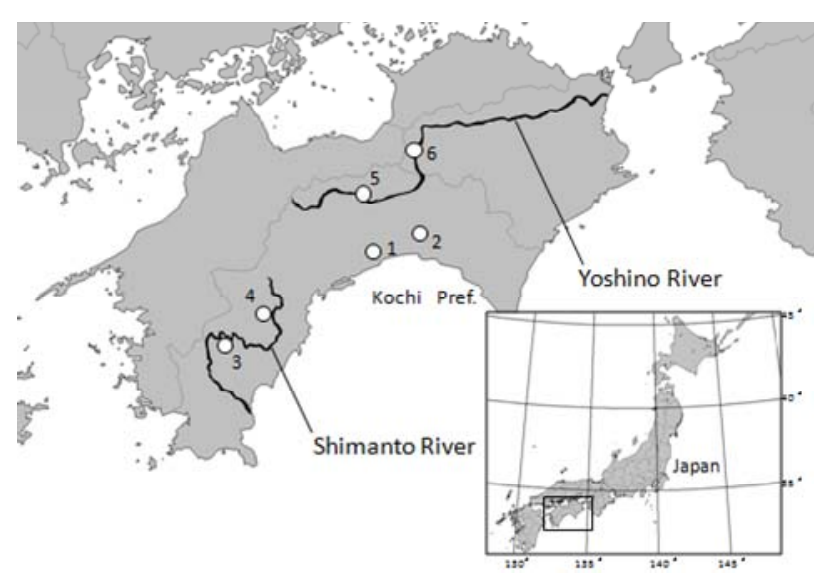

Figure 2. Sampling localities used in this study. Additional information is provided in Table 1. 
Table 1. Sampling localities used in this study.

\begin{tabular}{|c|c|c|c|c|}
\hline Species & Locality name & Locality no. & Locality & Latitude and longitude \\
\hline \multirow{2}{*}{ V. mandshurica var. mandshurica } & Asakura & 1 & $\begin{array}{c}\text { Kochi Prefecture, Kochi-City, Akebono-Cho, } \\
\text { Asakura }\end{array}$ & $\begin{array}{c}33^{\circ} 55^{\prime} \mathrm{N} \\
133^{\circ} 49^{\prime} \mathrm{E}\end{array}$ \\
\hline & Noichi & 2 & $\begin{array}{c}\text { Kochi Prefecture, Kounan-City, Noichi-Cho, } \\
\text { Nishino }\end{array}$ & $\begin{array}{l}33^{\circ} 56^{\prime} \mathrm{N} \\
133^{\circ} 69^{\prime} \mathrm{E}\end{array}$ \\
\hline \multirow{4}{*}{ V. mandshurica var. ikedaeana } & Towa & 3 & $\begin{array}{c}\text { Kochi Prefecture, Takaoka-Gun, Shimanto-Cho, } \\
\text { Towa }\end{array}$ & $\begin{array}{l}33^{\circ} 22^{\prime} \mathrm{N} \\
132^{\circ} 83^{\prime} \mathrm{E}\end{array}$ \\
\hline & Nakahira & 4 & $\begin{array}{c}\text { Kochi Prefecture, Takaoka-Gun, Yusuhara-Cho, } \\
\text { Nakahira }\end{array}$ & $\begin{array}{c}33^{\circ} 33^{\prime} \mathrm{N} \\
132^{\circ} 96^{\prime} \mathrm{E}\end{array}$ \\
\hline & Nanato & 5 & $\begin{array}{c}\text { Kochi Prefecture, Nagaoka-Gun, Motoyama-Cho, } \\
\text { Nanato }\end{array}$ & $\begin{array}{r}33^{\circ} 82^{\prime} \mathrm{N} \\
133^{\circ} 55^{\prime} \mathrm{E}\end{array}$ \\
\hline & Oboke & 6 & $\begin{array}{c}\text { Tokushima Prefecture, Miyoshi-City, Yamashiro-Cho, } \\
\text { Kamimyo }\end{array}$ & $\begin{array}{l}33^{\circ} 88^{\prime} \mathrm{N} \\
133^{\circ} 76^{\prime} \mathrm{E}\end{array}$ \\
\hline
\end{tabular}

Locality no. corresponds to that given in Figure 2.

off by using Suzuki's Universal Micro-Printing (SUMP) method. The number of epidermal cells was calculated by using following formula: leaf size/cell size. Replicas of each leaf $\left(1 \mathrm{~cm}^{2}\right)$ were prepared to determine the stomatal density (number per $\mathrm{mm}^{2}$ ) and to measure the epidermal cell size of 10 cells per leaf. These copied SUMP images were examined once for each individual, with a light microscope (CX41; Olympus Co., Tokyo, Japan). Statistical analyses were performed using Tukey's honestly significant difference (HSD) test and the Steel-Dwass test to compare the characteristics of $V$. mandshurica var. mandshurica and the rheophytic ecotype of $V$. mandshurica var. ikedaeana.

\section{Results}

\subsection{Morphological Analyses of $V$. mandshurica var. mandshurica and the Rheophytic Ecotype of $V$. mandshurica var. ikedaeana}

The leaf lengths of $V$. mandshurica var. mandshurica (2 populations-Asakura and Noichi) and V. mandshurica var. ikedaeana (4 populations - Towa, Nakahira, Nanato and Oboke) were $34.77 \pm 0.97 \mathrm{~mm}, 59.79 \pm 1.16 \mathrm{~mm}$, $31.13 \pm 1.99 \mathrm{~mm}, 31.65 \pm 1.84 \mathrm{~mm}, 32.94 \pm 1.62 \mathrm{~mm}$, and $35.62 \pm 1.68 \mathrm{~mm}$, respectively; the leaf widths were $21.73 \pm 2.14 \mathrm{~mm}, 29.93 \pm 1.57 \mathrm{~mm}, 8.35 \pm 0.37 \mathrm{~mm}$, $10.77 \pm 0.55 \mathrm{~mm}, 10.64 \pm 0.31 \mathrm{~mm}$, and $11.95 \pm 0.51$ $\mathrm{mm}$, respectively; and the average angles of the leaf base were $156.49 \pm 9.64$ degrees, $180.94 \pm 1.55$ degrees, $72.97 \pm 2.67$ degrees, $125.72 \pm 10.00$ degrees, $103.91 \pm$ 3.08 degrees, and $105.47 \pm 3.85$ degrees, respectively
(Table 2). The leaf thicknesses were $191.83 \pm 5.22 \mu \mathrm{m}$, $219.29 \pm 4.12 \mu \mathrm{m}, 311.52 \pm 10.02 \mu \mathrm{m}, 246.84 \pm 4.02 \mu \mathrm{m}$, $274.87 \pm 5.04 \mu \mathrm{m}$, and $252.74 \pm 4.30 \mu \mathrm{m}$, respectively. The resulting leaf sizes for $V$. mandshurica var. mandshurica and the rheophytic ecotype of $V$. mandshurica var. ikedaeana were $377.80 \pm 60.63 \mathrm{~mm}^{2}, 894.75 \pm 60.54$ $\mathrm{mm}^{2}, 129.98 \pm 19.72 \mathrm{~mm}^{2}, 170.41 \pm 21.80 \mathrm{~mm}^{2}, 175.28$ $\pm 17.26 \mathrm{~mm}^{2}$, and $212.86 \pm 21.37 \mathrm{~mm}^{2}$, respectively. With the exception of leaf length, all of the macromorphological leaf traits differed significantly between $V$. mandshurica var. mandshurica and the rheophytic ecotype of $V$. mandshurica var. ikedaeana.

The leaf index of $V$. mandshurica var. mandshurica $(1.60 \pm 0.07$ [Asakura], $2.04 \pm 0.05$ [Noichi]) was significantly lower than that of the rheophytic ecotype of $V$. mandshurica var. ikedaeana (3.70 \pm 0.12 [Towa], $2.94 \pm$ 0.08 [Nakahira], $2.34 \pm 0.12$ [Nanato], $3.27 \pm 0.10$ [Oboke]).

\subsection{Anatomical Analyses of $V$. mandshurica var. mandshurica and the Rheophytic Ecotype of $V$. mandshurica var. ikedaeana}

The cell sizes of $V$. mandshurica var. mandshurica (2 populations-Asakura and Noichi) and V. mandshurica var. ikedaeana (4 populations-Towa, Nakahira, Nanato and Oboke) were $6585.97 \pm 362.66 \mu \mathrm{m}^{2}, 8241.96 \pm$ $279.70 \mu \mathrm{m}^{2}, 5241.65 \pm 117.68 \mu \mathrm{m}^{2}, 6346.67 \pm 271.50$ $\mu \mathrm{m}^{2}, 6252.58 \pm 145.25 \mu \mathrm{m}^{2}$, and $6911.77 \pm 650.03 \mu \mathrm{m}^{2}$. The cell size did not differ significantly between $V$. mandshurica var. mandshurica and the rheophytic ecotype of V. mandshurica var. ikedaeana (Table 2). Based 
Table 2. Morphological and anatomical measurements of $V$. mandshurica var. mandshurica and $V$. mandshurica var. ikedaeana.

\begin{tabular}{|c|c|c|c|c|c|c|}
\hline \multirow{2}{*}{ Trait } & \multicolumn{2}{|c|}{ V. mandshurica var. mandshurica } & \multicolumn{4}{|c|}{ V. mandshurica var. ikedaeana } \\
\hline & Asakura & Noichi & Towa & Nakahira & Nanato & Oboke \\
\hline Leaf length (mm) & $34.77 \pm 0.97^{b}$ & $59.79 \pm 1.16^{\mathrm{a}}$ & $31.13 \pm 1.99^{\mathrm{b}}$ & $31.65 \pm 1.84^{\mathrm{b}}$ & $32.94 \pm 1.62^{\mathrm{b}}$ & $35.62 \pm 1.68^{b}$ \\
\hline Leaf width (mm) & $21.73 \pm 2.14^{\mathrm{b}}$ & $29.93 \pm 1.57^{\mathrm{a}}$ & $8.35 \pm 0.37^{\mathrm{d}}$ & $10.77 \pm 0.55^{\mathrm{cd}}$ & $10.64 \pm 0.31^{\mathrm{cd}}$ & $11.95 \pm 0.51^{\mathrm{c}}$ \\
\hline Leaf size $\left(\mathrm{mm}^{2}\right)$ & $377.80 \pm 60.63^{\mathrm{b}}$ & $894.75 \pm 60.54^{\mathrm{a}}$ & $129.98 \pm 19.72^{\mathrm{c}}$ & $170.41 \pm 21.80^{\mathrm{c}}$ & $175.28 \pm 17.26^{\mathrm{c}}$ & $212.86 \pm 21.37^{\mathrm{c}}$ \\
\hline Leaf index ${ }^{1}$ & $1.60 \pm 0.07^{\mathrm{e}}$ & $2.04 \pm 0.05^{\mathrm{d}}$ & $3.70 \pm 0.12^{\mathrm{a}}$ & $2.94 \pm 0.08^{b}$ & $2.34 \pm 0.12^{\mathrm{b}}$ & $3.27 \pm 0.10^{\mathrm{ab}}$ \\
\hline Leaf thickness $(\mu \mathrm{m})$ & $191.83 \pm 5.22^{\mathrm{c}}$ & $219.29 \pm 4.12^{\mathrm{b}}$ & $311.52 \pm 10.02^{\mathrm{a}}$ & $246.84 \pm 4.02^{\mathrm{a}}$ & $274.87 \pm 5.04^{\mathrm{a}}$ & $252.74 \pm 4.30^{\mathrm{a}}$ \\
\hline $\begin{array}{l}\text { Angle of leaf base } \\
\text { (degrees) }\end{array}$ & $156.49 \pm 9.64^{b}$ & $180.94 \pm 1.55^{\mathrm{a}}$ & $72.97 \pm 2.67^{\mathrm{d}}$ & $125.72 \pm 10.00^{\mathrm{c}}$ & $103.91 \pm 3.08^{\mathrm{c}}$ & $105.47 \pm 3.85^{\mathrm{c}}$ \\
\hline $\begin{array}{l}\text { Epidermal cell size } \\
\qquad\left(\mu \mathrm{m}^{2}\right)\end{array}$ & $6585.97 \pm 362.66^{\mathrm{ab}}$ & $8241.96 \pm 279.70^{\mathrm{a}}$ & $5241.65 \pm 117.68^{c}$ & $6346.67 \pm 271.50^{\mathrm{bc}}$ & $6252.58 \pm 145.25^{\mathrm{bc}}$ & $6911.77 \pm 650.03^{\mathrm{ab}}$ \\
\hline Epidermal cell number & $73544.4 \pm 7440.3^{\mathrm{a}}$ & $84750.8 \pm 6098.7^{\mathrm{a}}$ & $32302.3 \pm 4208.3^{b}$ & $30373.9 \pm 2768.2^{b}$ & $39203.6 \pm 2677.5^{\mathrm{b}}$ & $36797.0 \pm 3319.9^{b}$ \\
\hline $\begin{array}{l}\text { Stomatal density } \\
\left(\text { number per } \mathrm{mm}^{2}\right)\end{array}$ & $122.88 \pm 4.64^{b}$ & $158.02 \pm 4.42^{\mathrm{a}}$ & $121.27 \pm 3.74^{b}$ & $172.99 \pm 10.41^{\mathrm{a}}$ & $144.10 \pm 6.03^{\mathrm{ab}}$ & $173.02 \pm 8.83^{\mathrm{a}}$ \\
\hline Guard cell size $\left(\mu \mathrm{m}^{2}\right)$ & $122.45 \pm 5.51^{\mathrm{c}}$ & $132.81 \pm 4.91^{\mathrm{c}}$ & $250.39 \pm 4.02^{\mathrm{b}}$ & $281.95 \pm 8.40^{\mathrm{a}}$ & $285.19 \pm 6.56^{\mathrm{a}}$ & $266.67 \pm 3.51^{\mathrm{ab}}$ \\
\hline
\end{tabular}

All measurements are represented as mean \pm standard deviation. Columns marked by different letters showing significant differences according to Tukey's HSD test $(\mathrm{p}<0.05) ;{ }^{1}$ Nonparametric pairwise comparison was conducted by using the Steel-Dwass test.

on the leaf size and cell size, we calculated the number of epidermal cells per leaf. The cell numbers for $V$. mandshurica var. mandshurica and the rheophytic ecotype of V. mandshurica var. ikedaeana were $73544.4 \pm 7440.3$, $84750.8 \pm 6098.7,32302.3 \pm 4208.3,30373.9 \pm 2768.2$, $39203.6 \pm 2677.5$, and $39797.0 \pm 3319.9$, respectively. Leaves of $V$. mandshurica var. mandshurica contained a significantly higher number of cells than did those of the rheophytic ecotype of $V$. mandshurica var. ikedaeana. The stomatal density of $V$. mandshurica var. mandshurica (122.88 \pm 4.64 and $158.02 \pm 4.42)$ did not differ significantly from that of the rheophytic ecotype of $V$. mandshurica var. ikedaeana $(121.27 \pm 3.74,172.99 \pm$ $10.41,144.10 \pm 6.03$, and $173.02 \pm 8.83)$. By contrast, the stomatal size $\left(250.39 \pm 4.02 \mu \mathrm{m}^{2}\right.$ [Towa], $281.95 \pm$ $8.40 \mu \mathrm{m}^{2}$ [Nakahira], $285.19 \pm 6.56 \mu \mathrm{m}^{2}$ [Nanato], and $266.67 \pm 3.51 \mu \mathrm{m}^{2}$ [Oboke]) of the rheophytic ecotype of $V$. mandshurica var. ikedaeana was significantly larger than that of $V$. var. mandshurica $\left(122.45 \pm 5.51 \mu \mathrm{m}^{2}\right.$ [Asakura] and $132.81 \pm 4.91 \mu \mathrm{m}^{2}$ [Noichi]).

\section{Discussion}

The speciation of inland rheophyte species appears to be associated with stenophyllization, and rheophytes have been shown as scattered among various taxa, from bryophytes to angiosperms [5]. In the present study, we have demonstrated that rheophytic ecotype of $V$. mandshurica var. ikedaeana has a significantly narrower leaf than $V$. mandshurica var. mandshurica, indicating that $V$. mandshurica var. ikedaeana is the rheophytic species. Some other rheophytic species, such as Osmunda lancea Thunb. (Osmundaceae) [7,8] and Astilbe japonica (C. Morren et Decne.) A. Gray (Saxifragaceae) [22], were found in our sampling localities along the Shimanto and Yoshino rivers of Shikoku (data not shown). Moreover, rheophytes of $R$. ripense, Adenophora triphylla var. japonica, and Aster microcephalus var. ripensis were previously collected from neighbouring areas along these rivers [11-13]. Taken together, these findings suggest that strong selection pressures caused by high flooding frequency affects the leaf form along these riversides, thereby leading to the selection of rheophytic species.

Our results indicate that a decrease in the number of cells in a leaf contributes to stenophyllization of the rheophytic ecotype of $V$. mandshurica var. ikedaeana. This anatomical mechanism of stenophyllization is similar to that previously reported for R. ripense [13], R. indicum (L.) Sweet f. okutami T. Yamaz. [14], and F. japonicum var. luchuense $[9,23]$. These species are of different lineages from $V$. mandshurica var. ikedaeana, suggesting that the same stenophyllization process operates independently among rheophytic taxa. Previous anatomical studies have shown a decreased number of cells in all angiosperm rheophytes [9-14,23], indicating that this is a common mechanism contributing to stenophyllization. Based on angiosperm phylogeny [15-18], variation of cell size in the rheophytic Ad. triphylla var. 
japonica and As. microcephalus var. ripensis may be an additional process of stenophyllization in the advanced lineage of the Asterid Group. By contrast, alterations in the cell-elongation process appear to be responsible for the narrow, thickened leaves of fern rheophytes $[6,7]$. Therefore, the stenophyllization process of rheophytes differs between angiosperms and ferns.

Our morphological data for the rheophytic ecotype of $V$. mandshurica var. ikedaeana indicate that the angle of the leaf base is strongly correlated with the length and width of a leaf. Moreover, the decreasing angle of the leaf base results in a lanceolate leaf, indicating that stenophyllization of leaves of the rheophytic ecotype of $V$. mandshurica var. ikedaeana occurred with the transition from triangular- and oblong-lanceolate leaves to hastate leaves. The general tendency for plants growing closer to streams to have lanceolate leaves may be caused by selection pressures of habitats along a gradually decreasing flooding frequency, from streambed to inland [24]. Therefore, based on its macromorphological characteristics and lanceolate leaves, the rheophytic ecotype of $V$. mandshurica var. ikedaeana appears to be tolerant of swift-running streams.

In the present study, we further demonstrated that the leaf thickness and stomatal size of the rheophytic ecotype of $V$. mandshurica var. ikedaeana were significantly larger than those of $V$. mandshurica var. mandshurica. Previous studies of $F$. japonicum var. luchuense and $R$. ripense showed that individuals growing on riverbanks had larger leaf thicknesses than did those of inland plants $[9,14,23]$. Taken together, these findings indicate that increased leaf thickness is a general tendency among rheophytes $-V$. mandshurica var. ikedaeana, $R$. ripense, and $F$. japonicum var. luchuense show a similar pattern of differentiation but are widely separated phylogenetically. Moreover, leaf thickness and stomatal size are positively correlated with the mean solar radiation during leaf expansion $[25,26]$. In general, stomata are the main gates for gaseous exchange of leaves [27-29]. The guard cells that surround the stomata contain chloroplasts, and are therefore able to increase their sugar concentration; this, in turn, causes water absorption and swelling of the cells [30,31]. In addition, stomatal conductance depends on leaf characteristics such as size, number, and stomatal density [32-34]. The rheophytic ecotype of $V$. mandshurica var. ikedaeana grows mainly in riverside habitats - on sunny, moist rocks and on riverbanks - in southern Shikoku, Japan; therefore, the condition of high irradiance along the riverside may lead to increased leaf thickness and stomatal size.

In summary, we have analysed the evolution of the rheophytic ecotype of $V$. mandshurica var. ikedaeana, by using morphological and anatomical data. The results provide an unbiased interpretation of the rheophytic evolution of angiosperms. Our data clearly indicate the rheophytic process of $V$. mandshurica var. ikedaeana, but do not provide a definitive interpretation of the rheophytic pattern of adaptation. In the Violaceae, for example, [35] reported that $V$. grypoceras A. Gray var. ripensis $\mathrm{N}$. Yamada et Okamoto had a rheophytic distribution on some riversides in central to western Japan, and that the leaves were smaller and narrower than those of its closely related variety, V. grypoceras var. grypoceras. However, whether the process is caused by a decrease in the size or number of leaf cells remains to be determined. Further studies based on samplings that are more comprehensive and additional taxa are required to support our working hypothesis of cell alteration in rheophytes. Thus, we believe that our morphological and anatomical data will stimulate future studies of diversity in rheophytes.

\section{Acknowledgements}

We thank Ogawa K, Matsuyama K, Yoshimi Y, Yokoyama $\mathrm{N}$, Isomoto $\mathrm{S}$, Miyata $\mathrm{H}$, Tsuchiya $\mathrm{Y}$, Muroi $\mathrm{M}$, Kakimoto N, Kumekawa Y, Nishimura C, Uemoto C, and Inoue $\mathrm{S}$ for their help during our research. This study was partly supported by the River Fund in charge of the Foundation of River and Watershed Environment Management (FOREM), Japan and a Grant-in-Aid for Scientific Research from the Ministry of Education, Science and Culture of Japan (to JY and TF).

\section{REFERENCES}

[1] C. W. P. M. Blom and L. A. C. J. Voesenek, "Flooding: The Survival Strategies of Plants," Trends in Ecology \& Evolution, Vol. 11, No. 7, 1996, pp. 290-295. doi:10.1016/0169-5347(96)10034-3

[2] P. J. A. Vervuren, C. W. P. M. Blom and H. de Kroon, "Extreme Flooding Events on the Rhine and the Survival and Distribution of Riparian Plant Species," Journal of Ecology, Vol. 91, No. 1, 2003, pp. 135-146. doi:10.1046/j.1365-2745.2003.00749.x

[3] W. H. J. M. van Eck, H. M. van de Steeg, C. W. P. M. Blom and H. de Kroon, "Is Tolerance to Summer Flooding Correlated with Distribution Patterns in River Floodplains? A Comparative Study of 20 Terrestrial Grassland Species," Oikos, Vol. 107, No. 2, 2004, pp. 393-405. doi:10.1111/j.0030-1299.2004.13083.x

[4] L. A. C. J. Voesenek, J. H. G. M. Rijnders, A. J. M. Peeters, H. M. van de Steeg and H. de Kroon, "Plant Hormones Regulate Fast Shoot Elongation under Water: From Genes to Communities," Ecology, Vol. 85, No. 1, 2004, pp. 16-27. doi:10.1890/02-740

[5] C. G. G. J. van Steenis, "Rheophyte of the World," Sijthoff and Noordhoff, Alpen aan den Rijn, 1981.

[6] M. Kato and R. Imaichi, "Leaf Anatomy of Tropical Fern Rheophytes with Its Evolutionary and Ecological Impli- 
cations," Canadian Journal of Botany, Vol. 70, No. 1, 1992, pp. 165-174. doi:10.1139/b92-022

[7] R. Imaichi and M. Kato, "Comparative Leaf Development of Osmunda lancea and O. japonica (Osmundaceae): Heterochronic Origin of Rheophytic Stenophylly," The Botanical Magazine, Vol. 105, No. 2, 1992, pp. 199-213. doi:10.1007/BF02489415

[8] R. Imaichi and M. Kato, "Comparative Leaf Morphology of Young Sporophytes of Rheophytic Osmunda lancea and Dryland O. japonica," Journal of Plant Research, Vol. 106, No. 1, 1993, pp. 37-45. doi:10.1007/BF02344371

[9] M. Usukura, R. Imaichi and M. Kato, "Leaf Morphology of a Facultative Rheophyte, Farfugium japonicum var. luchuense (Compositae)," Journal of Plant Research, Vol. 107, No. 3, 1994, pp. 263-267. doi:10.1007/BF02344253

[10] H. Tsukaya, "Leaf Anatomy of a Rheophyte, Dendranthema yoshinaganthum (Asteraceae), and of Hybrids between D. yoshinaganthum and a Closely Related NonRheophyte, D. indicum," Journal of Plant Research, Vol. 115, No. 5, 2002, pp. 329-333. doi:10.1007/s10265-002-0041-y

[11] Y. Yamada, H. Hayakawa, Y. Minamiya, K. Ito, Z. Shibayama, R. Arakawa and T. Fukuda, "Comparative Morphology and Anatomy of Rheophytic Aster microcephalus (Miq.) Franch. et Sav. var. ripensis Makino (Asteraceae)," Journal of Phytogeography and Taxonomy, Vol. 59, No. 1, 2011, pp. 35-42.

[12] K. Ohga, M. Muroi, H. Hayakawa, K. Ito, J. Yokoyama, S. Tebayashi, R. Arakawa and T. Fukuda, "Comparative Morphology and Anatomy of Non-Rheophytic and Rheophytic Types of Adenophora triphylla var. japonica (Campanulaceae)," American Journal of Plant Science, Vol. 3, No. 6, 2012, pp. 805-809. doi:10.4236/ajps.2012.36097

[13] H. Setoguchi and G. Kajimura, "Leaf Morphology of the Rheophyte, Rhododendron indicum f. otakumi (Ericaceae)," Acta Phytotaxomica et Geobotanica, Vol. 55, No. 1, 2004, pp. 45-54.

[14] R. Ueda, Y. Minamiya, A. Hirata, H. Hayakawa, Y. Muramatsu, M. Saito and T. Fukuda, "Morphological and Anatomical Analyses of Rheophytic Rhododendron ripense Makino (Ericaceae)," Plant Species Biology, Vol. 27, No. 3, 2012, pp. 223-240. doi:10.1111/j.1442-1984.2011.00345.x

[15] M. W. Chase, D. E. Soltis, R G. Olmstead, D. Morgan, D. H. Les, B. D. Mishler, M. R. Duvall, R. A. Price, H. G. Hills and Y. L. Qiu, "Phylogenetics of Seed Plants: An Analysis of Nucleotide Sequences from the Plastid Gene rbcL," Annals of the Missouri Botanical Garden, Vol. 80, No. 3, 1993, pp. 528-580. doi:10.2307/2399846

[16] D. E. Soltis, P. S. Soltis, M. W. Chase, M. E. Mort, D. C. Albach, M. Zanis, V. Savolainen, W. H. Hahn, S. B. Hoot, M. F. Fay, M. Axtell, S. M. Swenson, M. A. Prince, W. J. Kress, K. C. Nixon and J. S. Farris, "Angiosperm Phylogeny Inferred from a Combined Data Set of 18S rDNA, rbcL and atpB Sequences," Botanical Journal of the Linnean Society, Vol. 133, No. 4, 2000, pp. 381-461.
[17] V. Savolainen and M. W. Chase, "A Decade of Progress in Plant Molecular Phylogenetics," Trends in Genetics, Vol. 19, No. 12, 2003, pp. 717-724. doi:10.1016/j.tig.2003.10.003

[18] P. S. Soltis and D. S. Soltis, "The Origin and Diversification of Angiosperms," American Journal of Botany, Vol. 91, No. 10, 2004, pp. 1614-1626. doi:10.3732/ajb.91.10.1614

[19] S. Akiyama, H. Ohba and S. Tabuchi, "Violaceae," In: K. Iwatsuki, T. Tamazaki, D. E. Boufford and H. Ohba, Eds., Flora of Japan Vol. IIc., Kodansha, Tokyo, 1993, pp. 161-190.

[20] M, Igari, “Wild Violets of Japan," Yama-to-Keikoku-sha, Tokyo, 1996.

[21] H. Tsukaya, "The Leaf Index: Heteroblasty, Natural Variation, and the Genetic Control of Polar Process of Leaf Expansion," Plant and Cell Physiology, Vol. 43, No. 4, 2002, pp. 372-378. doi:10.1093/pcp/pcf051

[22] T. Yamanaka and K. Takezaki, "Distribution and Ecology of Rhododendron ripense Makino, with Reference to the Vegetation and Flora on Rocky River-Bank," Journal of Japanese Botany, Vol. 34, 1959, pp. 215-224.

[23] N. Nomura, H. Setoguchi and T. Takaso, "Functional Consequences of Stenophylly for Leaf Productivity: Comparison of the Anatomy and Physiology of a Rheophyte, Farfugium japonicum var. luchuence, and a Related NonRheophyte, F. japonicum (Asteraceae)," Journal of Plant Research, Vol. 119, No. 6, 2006, pp. 645-656. doi:10.1007/s10265-006-0024-5

[24] R. Imaichi and M. Kato, "Speciation and Morphological Evolution in Rheophytes," In: K. Iwatsuki and P. H. Raven, Eds., Evolution and Diversification of Landplants, Springer-Verlag, Tokyo, 1997, pp. 309-318. doi:10.1007/978-4-431-65918-1_15

[25] Ü. Niinemets, "Components of Leaf Dry Mass per AreaThickness and Density-Alter Leaf Photosynthetic Capacity in Reverse Directions in Woody Plants," New Phytolgist, Vol. 144, No. 1, 1999, pp. 35-47. doi:10.1046/j.1469-8137.1999.00466.x

[26] Ü. Niinemets, "Global-Scale Climatic Controls of leaf Dry Mass per Area, Density and Thickness in Trees and Shrubs," Ecology, Vol. 82, No. 2, 2001, pp. 453-469. doi:10.1890/0012-9658(2001)082[0453:GSCCOL]2.0.C $\mathrm{O} ; 2$

[27] K. Raschke, "Stomatal Action," Annual Review of Plant Physiology, Vol. 26, No. 1, 1975, pp. 309-340. doi:10.1146/annurev.pp.26.060175.001521

[28] P. G. Schoch, C. Zinsou and M. Sibi, "Dependence of the Stomatal Index on Environmental Factors Differentiation in Leaves of Vigna sinensis L. 1. Effect of Light Intensity," Journal of Experimental Botany, Vol. 31, No. 5, 1980, pp. 1211-1216. doi:10.1093/jxb/31.5.1211

[29] E. E. Brent and O. Ram, "Analyses of Assumptions and Errors in the Calculation of Stomatal Conductance from Sap Flux Measurements," Tree Physiology, Vol. 20, No. 9, 2000. pp. 579-589. doi:10.1093/treephys/20.9.579

[30] P. G. Jarvis, "The Interpretation of Variations in Leaf 

Viola mandshurica var. ikedaeana (Violaceae)

Water Potential and Stomatal Conductance Found in Canopies in the Field," Philosophical Transactions of the Royal Society of London, Series B, Biological Sciences, Vol. 273, No. 927, 1976, pp. 93-610. doi:10.1098/rstb.1976.0035

[31] B. E. Ewers, R. Oren, K. H. Johnsen and J. J. Landsberg, "Estimating Maximum Mean Canopy Stomatal Conductance for Use in Models," Canadian Journal of Forest Research, Vol. 31, No. 2, 2001, pp. 198-207.

[32] D. F. Cole and A. K. Dobrenz, "Stomata Density of Alfalfa (Medicago sativa L.)," Crop science, Vol. 10, No. 1, 1970, pp. 61-63.

doi:10.2135/cropsci1970.0011183X001000010024x

[33] D. Teare, C. J. Peterson and A. G. Law, "Size and Fre- quency of Leaf Stomata in Cultivars of Triticum aestivum and Other Triticum Species," Crop Science, Vol. 11, No. 4, 1971, pp. 496-498. doi:10.2135/cropsci1971.0011183X001100040010x

[34] J. Ciha and W. A. Brown, "Stomatal Size and Frequency in Soybean," Crop Science, Vol. 15, No. 3, 1975, pp. 309-313. doi:10.2135/cropsci1975.0011183X001500030008x

[35] N. Yamada, T. Suzuki and M. Okamoto, "A New Rheophilous Variety, Viola grypoceras var. ripensis, from Central and Western Honshu, Japan," Bulletin of the Osaka Museum of Natural History, Vol. 50, 1996, pp. 18 . 